\title{
タンタルおよびニオブの高温希薄酸水溶液中に おける耐食性被膜の構造*
}

\section{中山忠 行** 坂 敏 明***}

Tadayuki Nakayama and Toshiaki Osaka : Structure of Corrosion-Resisting Films Formed on Tantalum and Niobium in High-Temperature Dilute Acid Aqueous Solutions. An attempt was made to study the structure and the corrosion-resisting nature of oxide films formed on $\mathrm{Ta}$ and $\mathrm{Nb}$ in high-temperature dilute $\mathrm{HNO}_{3}, \mathrm{H}_{2} \mathrm{SO}_{4}$ or $\mathrm{HCl}$.

The results obtained are as follows: (1) Electron diffraction patterns of oxide films formed on Ta in $2 \mathrm{~N} \mathrm{HNO}_{3}$ and $\mathrm{Nb}$ in $0.1 N \mathrm{HNO}_{3}$ at $200^{\circ} \sim 300^{\circ} \mathrm{C}$ for $1 \mathrm{hr}$ indicated the presence of only the normal rutile-type structure, thought to be $\mathrm{TaO}_{2}$ and $\mathrm{NbO}_{2}$, respectively. However, the film formed on $\mathrm{Nb}$ in $2 \mathrm{~N} \mathrm{HNO}_{3}$ at $200^{\circ} \mathrm{C}$ for $1 \mathrm{hr}$ gave a diffraction pattern corresponding to a new tetragonal-type structure ( $\mathrm{T}_{1}$-phase). The unit cell dimensions of the $\mathrm{T}_{1}$-phase were calculated to be $a_{0}=8.94 \AA, c_{0}=11.9 \AA$, $c_{0} / a_{0}=1.33$. (2) Oxide films formed on $\mathrm{Ta}$ in $2 \mathrm{~N} \mathrm{H}_{2} \mathrm{SO}_{4}$ at $200^{\circ} \sim 300^{\circ} \mathrm{C}$ and on $\mathrm{Nb}$ in $0.1 \mathrm{~N} \mathrm{H}_{2} \mathrm{SO}_{4}$ at $200^{\circ} \mathrm{C}$ for $1 \mathrm{hr}$ were also composed of the normal rutile-type crystals. Another tetragonal-type oxide $\left(\mathrm{T}_{2}\right.$-phase), however, was formed on $\mathrm{Nb}$ in $2 \mathrm{~N} \mathrm{H}_{2} \mathrm{SO}_{4}$ at $200^{\circ} \sim 300^{\circ} \mathrm{C}$ for $1 \mathrm{hr}$, with $a_{0}=10.5 \AA$, $c_{0}=5.85 \AA, c_{0} / a_{0}=0.56$. (3) The presence of an amorphous film was observed by heating Ta in $2 \mathrm{~N}$ $\mathrm{HCl}$ or $\mathrm{Nb}$ in $0.1 \mathrm{~N} \mathrm{HCl}$ at $200^{\circ} \sim 300^{\circ} \mathrm{C}$ for $1 \mathrm{hr}$. Therefore it is considered that the film acts as a protective barrier under the present experimental conditions. Further, from the above considerations and the fact that the $\mathrm{T}_{1}$-phase was formed in $0.5 \mathrm{~N} \mathrm{HCl}$ at $200^{\circ} \mathrm{C}$, the $\mathrm{T}_{2}$-phase in $2 \mathrm{~N} \mathrm{HCl}$ at $200^{\circ} \mathrm{C}$, and the $\delta$-phase $\left(\mathrm{Nb}_{2} \mathrm{O}_{5}\right)$ mainly in $2 \mathrm{~N} \mathrm{HCl}$ at $250^{\circ} \mathrm{C}$, it can be deduced that such a phase transition as $\mathrm{NbO}_{2} \rightarrow \mathrm{T}_{1}$-phase $\rightarrow \mathrm{T}_{2}$ - phase $\rightarrow \mathrm{Nb}_{2} \mathrm{O}_{5}$ occurred.

(Received August 24, 1970)

**早稲田大学理工学部金属工学科 (Department of Metallurgy, Faculty of Science and Engineering, Waseda University, Tokyo)
*** 早稲田大学大学院 (Graduate School, Waseda Uni- versity, Tokyo)

* 1970 年 4 月本会東京大会に一部発表 


\section{I. 緒 言}

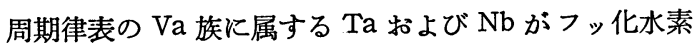
酸ならびに発煙硫酸を除くほとんどあらゆる無機酸に対し て非常に優れた耐食性を示すことはよく知られた事実であ り，特に Ta はその耐酸性に扔いて Nb の約 10 倍という きわめて優れた性質をもち(1)，近年熱交換器や電解槽など の耐食構造用材料として注目を浴びてきている.それゆ兄 これら金属の各種酸に対する耐食性を知るととすに，その 表面に形成される保護被膜の構造ならびに組成を調べるこ とは重要であると思われる。しかしながら従来 Ta および $\mathrm{Nb}$ の各種無機酸中における耐食性被膜の構造に関しては ほとんど報告がなされていない，そこで本研究に扔いては 酸化性酸として $\mathrm{HNO}_{3}$ 非酸化性酸として $\mathrm{H}_{2} \mathrm{SO}_{4}$ ならびに $\mathrm{HCl}$ など代表的な無機酸中に打いてこれら金属表面に生成 する酸化被膜の構造を反射ならびに透過電子回折および特 性X線分析により究明し，これら酸の希薄水溶液中に怙け る耐食性と被膜構造との関連性を合わせ検討した。

\section{II. 試料および実験方法}

実験に用いたのは Table 1 ならびに Table 2 に示す組 成の $\mathrm{Ta}$ 抢よび $\mathrm{Nb}$ の板状試料である.これよりいずれる 大きさ約 $10 \times 10 \times 1 \mathrm{~mm}$ の試片を切り取り，エメリー紙で \#05まで研摩した後, メチルアルコール,アセトンおよび エチルエーテルで脱脂洗浄して供試試料とした。 また腐食 試験にはいずれも0.1 2 $\mathrm{N}$ の濃度の $\mathrm{HNO}_{3}, \mathrm{H}_{2} \mathrm{SO}_{4}, \mathrm{HCl}$ を用い, 試片をこれら水溶液各 $10 \mathrm{cc}$ ととにパイレック

Table 1 Trace impurities in Ta

\begin{tabular}{cl|cc}
\hline \hline \multicolumn{2}{c|}{ Element (\%) } & \multicolumn{2}{|c}{ Element (\%) } \\
\hline $\mathrm{Al}$ & 0.001 & $\mathrm{~N}$ & 0.002 \\
$\mathrm{C}$ & 0.004 & $\mathrm{Nb}$ & 0.005 \\
$\mathrm{Cr}$ & 0.001 & $\mathrm{Ni}$ & 0.002 \\
$\mathrm{Cu}$ & 0.0003 & $\mathrm{O}$ & 0.005 \\
$\mathrm{Fe}$ & 0.001 & $\mathrm{Si}$ & 0.001 \\
$\mathrm{H}$ & 0.001 & $\mathrm{Ti}$ & 0.001 \\
$\mathrm{Mg}$ & 0.0001 & & \\
\hline
\end{tabular}

Table 2 Trace impurities in $\mathrm{Nb}$

\begin{tabular}{cc|cc}
\hline \hline \multicolumn{2}{c|}{ Element } & (ppm) & \multicolumn{2}{c}{ Element $(\mathrm{ppm})$} \\
\hline $\mathrm{C}$ & 30 & $\mathrm{O}_{2}$ & 115 \\
$\mathrm{H}_{2}$ & 13.1 & $\mathrm{~N}_{2}$ & 10 \\
$\mathrm{Ta}$ & 550 & $\mathrm{Ti}$ & $<10$ \\
$\mathrm{Fe}$ & 60 & $\mathrm{Mn}$ & 10 \\
$\mathrm{Si}$ & 20 & $\mathrm{Sn}$ & $<10$ \\
$\mathrm{Ni}$ & $<10$ & $\mathrm{Cr}$ & $<10$ \\
$\mathrm{Ca}$ & $<10$ & $\mathrm{Na}$ & $\mathrm{Trace}$ \\
$\mathrm{Al}$ & 30 & $\mathrm{Mo}$ & $<10$ \\
$\mathrm{Zr}$ & 100 & $\mathrm{Co}$ & $<10$ \\
$\mathrm{Mg}$ & $<10$ & $\mathrm{~B}$ & $<10$ \\
$\mathrm{~W}$ & 100 & & \\
\hline
\end{tabular}

(1) L. L. Shreir : Corrosion (Vol.1), Newnes, London, (1963) , 5, 19.
スガラス管に封入し,続いて容量 $1 \mathrm{~L}$ の 18-8 ステンレス鋼 製のオートクレーブ中で $200^{\circ} \sim 300^{\circ} \mathrm{C}$ の温度にて $1 \mathrm{hr} こ$ れらの試料の酸化を行なった，これら酸化した試料の表面 はいずれも干涉色被膜によって被覆されたが，この酸化膜 はカーボン蒸着によりその表面を補強した後, 試料表面に 約 $2 \times 2 \mathrm{~mm}^{2}$ の碁艋目状の下地金属に達する傷をつけ室温 に保持した $0.5 \sim 1 \mathrm{vol} \% \mathrm{HF}$ 水溶液中で約 $48 \mathrm{hr}$ 浸漬する ことにより䟝離した。また䟝離後の同一被膜で反射電子回 折による回折像と透過電子回折によるそれとの明らかに異 なる場合すすなわち生成被膜が䟝離液として用いた希 $\mathrm{HF}$ と反応を起こしたと考兄られる場合のあったことからと の種の被膜の㕷離には約 $4 \%$ の $\mathrm{Br}_{2}$-メタノール溶液を使用 した．な扣これら酸化被膜の電子回折ならびに電顕直接観 察には加速電圧 $100 \mathrm{kV}$ の日立製 HU-11 D 型を用い, かつ 生成被膜を構成する成分元素を調べるため $25 \mathrm{kV}$ の加速 電圧で制限視野回折と同一視野のX線マイクロアナライザ 一によるX線スペクトルの検出を行なった.

\section{III. 実験結果および考察}

\section{1. $\mathrm{HNO}_{3}$ 水溶液における酸化被膜の構造}

$\mathrm{Ta}$ 試片を $2 \mathrm{NHNO}_{3}$ 中で $200^{\circ} \mathrm{C}, 1 \mathrm{hr}$ 酸化したところ, その表面には淡黄色を呈する干涉色被膜が形成され，続い て同条件下で $300^{\circ} \mathrm{C}, 1 \mathrm{hr}$ 加熱のさいにはその表面は黄褐 色の被膜によって被覆された。.Photo. 1 は $300^{\circ} \mathrm{C}, 1 \mathrm{hr}$ の 酸化後, 1 vol\% HF にて試料表面から剝離した被膜の透過 電子顕微鏡写真であるが，これより生成被膜がかなり密な 微結晶からなっていることがわかる.つぎに生成被膜の電 子回折の結果, $200^{\circ} \mathrm{C}$ ならびに $300^{\circ} \mathrm{C}$ のいずれの酸化の場 合にも，その反射叔よび透過回折像はPhoto. 2 にみられ るような rutile 型結晶の存在を示したことからっこれらの 被膜は $\mathrm{TaO}_{2}$ からなるものと考兄られる. 続いてこの回折 像より求められた格子面間隔をもとに格子定数を計算した



Photo.1 Transmission electron micrograph of oxide film formed on Ta in $2 \mathrm{~N}$ $\mathrm{HNO}_{3}$ at $300^{\circ} \mathrm{C}$ for $1 \mathrm{hr}$ 
ところ $a_{0}=4.75 \AA, c_{0}=3.10 \AA, c_{0} / a_{0}=0.65$ の值が得ら れた.ところが Schönberg(2) の報告によると， $\mathrm{Ta}_{2} \mathrm{O}_{5}$ の炭素 還元で作られた $\mathrm{TaO}_{2}$ の格定定数は $a_{r}=4.709 \AA, c_{r}=$ $3.065 \AA$ の值であり，寺尾 ${ }^{(3)}$ の報告によるそれは $a_{r}=4.721$ $\AA, c_{r}=3.078 \AA$ である. この事実から $\mathrm{HNO}_{3}$ 中で生成し た rutile 型酸化物は電子回折の測定精度を考慮に入れても な敃従来の $\mathrm{TaO}_{2}$ 上りも格子がわずかながら膨張している と考党られる．さらにまた寺尾 ${ }^{(4)}$ が純粋の $\mathrm{TaO}_{2}$ は固体状 態では存在しにくく，何か不純物の混じることが必要らし いと述べていることから，X線マイクロアナライザーによ り生成被膜のX線スペクトル分析を行なったが，検出感度 内では Ta 以外の成分元素は見い出せなかった。

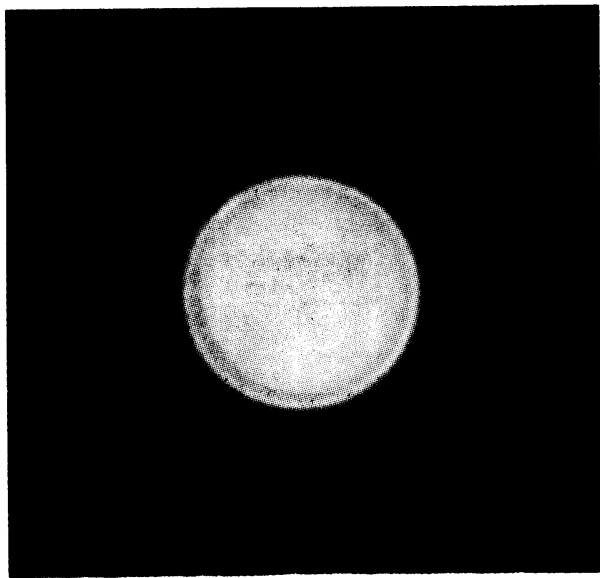

Photo.2 Electron diffractogram of rutiletype crystals formed on Ta in $2 \mathrm{~N}$ $\mathrm{HNO}_{3}$ at $300^{\circ} \mathrm{C}$ for $1 \mathrm{hr}$

一方 $\mathrm{Nb}$ 試片を $\mathrm{Ta}$ と同条件下の $2 \mathrm{NHNO}_{3}$ 中で $200^{\circ} \mathrm{C}$, $1 \mathrm{hr}$ 酸化したところ, その表面は黄褐色を呈する干涉色被 膜によって被覆され，0.5\% HF にて剝離後電顕直接観察 を行なった結果, Photo.3のようなやはり微細な結晶の存 在がみられた.Photo.4 はこの生成被膜の透過電子回折像 である.ところがこの回折像より求められた格子面間隔は 今まで報告されている $\mathrm{Nb}$ 酸化物のいずれにも該当せず， なおその上A.S.T.M.Powder data cards によってもこれ に類似する結晶系をるつ物質は見当らなかった．そこで Bjurström の図表 ${ }^{(5)}$ を用いて指数付けを行なった結果, こ の生成被膜が正方晶物質であることがわかり，Table 3 に 示すような指数が与えられた. この指数をもとに格子定数 を計算したところ， $a_{0}=8.94 \AA ， c_{0}=11.9 \AA ， c_{0} / a_{0}=1.33$ なる值がられこれと Table 3 の指数を用いて格子面間隔 の計算値を求めた結果, Table 3 から明らかなように測定值 と計算值のよい一致をみた。 しかしながらこれからだけで はこの物質が薄膜であることと多結晶体であることから，

(2) N.Schönberg : Acta Chem.Scand., 8(1954), 240.

(3) N.Terao : Jap.J.Appl.Phys., 6 (1967), 21.

（4）寺尾：金属学会会報, 8(1969), 509 .

(5) C. W. Bunn : Chemical Crystallography 2nd Ed., Oxford, (1961).
生成被膜の組成についてなんら手がかりが得られないそ のためこの物質の既知組成からなる酸化物への相転移を期 待し, $\mathrm{Nb}$ 試片を $\mathrm{HNO}_{3}$ 水溶液中で $250^{\circ} \mathrm{C}, 300^{\circ} \mathrm{C}$ とより

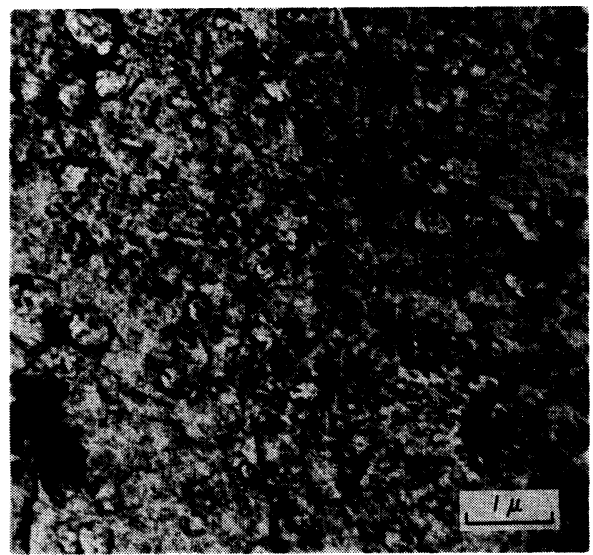

Photo.3 Transmission electron micrograph of oxide film formed on $\mathrm{Nb}$ in $2 \mathrm{~N}$ $\mathrm{HNO}_{3}$ at $200^{\circ} \mathrm{C}$ for $1 \mathrm{hr}$

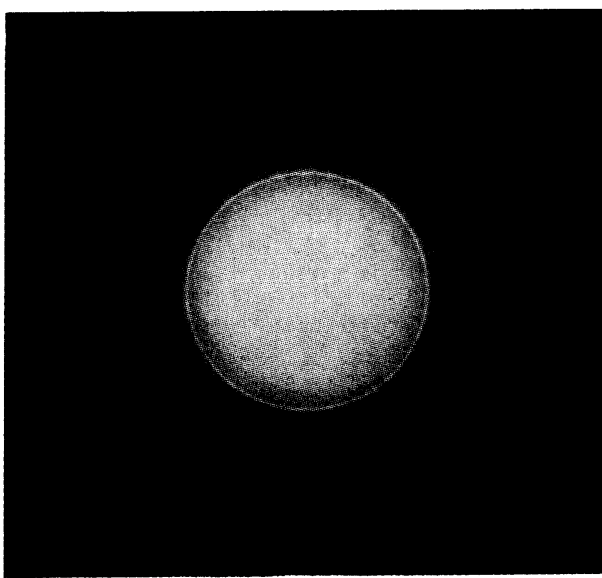

Photo. 4 Electron diffractogram of $\mathrm{T}_{1}$-phase formed on $\mathrm{Nb}$ in $2 \mathrm{~N} \mathrm{HNO}_{3}$ at $200^{\circ} \mathrm{C}$ for $1 \mathrm{hr}$

Table 3 Interplanar spacings $(d, \check{A})$, intensities $(I)$ and indices $(h k l)$ of $\mathrm{T}_{1}$-phase formed on $\mathrm{Nb}$ in $2 \mathrm{~N} \mathrm{HNO}_{3}$ at $200^{\circ} \mathrm{C}$ for $1 \mathrm{hr}$

\begin{tabular}{l|c|c|c}
\hline \hline$d_{\text {obs. }}$ & $d_{\text {calc. }}$ & $I_{\text {obs. }}$ & $h k l$ \\
\hline 3.64 & 3.62 & v.st. & 103 \\
3.31 & 3.32 & m.st. & 212 \\
2.98 & 2.98 & m.st. & 300 \\
2.79 & 2.79 & v.w. & 222 \\
2.69 & 2.69 & st. & 114 \\
2.46 & 2.47 & st. & 204 \\
2.35 & 2.37 & v.v.w. & 005 \\
2.22 & 2.22 & m.st. & 115 \\
2.17 & 2.17 & m.st. & 410,224 \\
1.91 & 1.90 & v.w. & 324,225 \\
1.82 & 1.82 & m.st. & 315 \\
1.81 & 1.81 & m.st. & 206 \\
1.73 & 1.74 & m.st. & 334 \\
1.71 & $1.71_{5}$ & w. & 325 \\
1.69 & 1.68 & w. & 226 \\
\hline
\end{tabular}


高温で酸化を行なったにもかかわらず，同じ正方晶結晶被 膜の生成をみた. そこでつぎに $\mathrm{HNO}_{3}$ 水溶液の濃度を低く し $0.1 \mathrm{~N} \mathrm{HNO}_{3}$ 中で $200^{\circ} \mathrm{C}, 1 \mathrm{hr}$ 酸化を試みたところ, $\mathrm{Nb}$ 表面には淡黄色の被膜が形成され，反射電子回折の結果 Photo. 5 に示すよ $5 な$ 明瞭な rutile 型回折環が得られた。 この被膜を $4 \% \mathrm{Br}_{2}$-メタノール溶液で剥離後 $\mathrm{X}$ 線スペクト ル分析を行なった結果, $\mathrm{Nb}$ の特性 X線のみを検出したこ とから生成被膜は $\mathrm{NbO}_{2}$ からなるものと考えられるが，こ こで回折像が理想的な rutile 型構造を示していることを問 題としなければならない.なぜなら従来 $\mathrm{NbO}_{2}$ は前述の $\mathrm{TaO}_{2}{ }^{(2)}$ (3) と異なり理想的な rutile 型構造ではなく, 理想的 な原子位置からのずれが重格子反射を生じ， $a=2 \sqrt{2} a_{r}=$ $13.71 \AA . c=2 c_{r}=5.985 \AA^{(6)}$ (ここで $a_{r}=4.846 \AA$. $\left.2.993 \mathrm{~A}^{(7)}\right)$ なる格子定数をすつと報告されているからであ る. その重格子反射は 100 を最強とした相対強度で $30 \sim 50$ の值をむつものもかなりあり ${ }^{(6)}$, Photo. 5 が重格子反射を 含む $\mathrm{NbO}_{2}$ であるならば当然理想的な rutile 型の回折反射 以外の反射が観察されるはずである. またこの被膜の透過 電子回折像から求めた格子定数は $\mathrm{Ta}$ の場合と全く同じ値 $a_{0}=4.75 \AA ， c_{0}=3.10 \AA$ を示した. それゆえ Тa ならびに $\mathrm{Nb}$ 表面に $\mathrm{HNO}_{3}$ 水溶液中で生成した理想的な rutile 型構 造をるつ $\mathrm{TaO}_{2}$ および $\mathrm{NbO}_{2}$ 被膜の生成機構について考兄 るとき, これらの被膜の生成には水の存在が大きな寄与を なしていると思われるが，これは今のところ推論の域を出 ない.

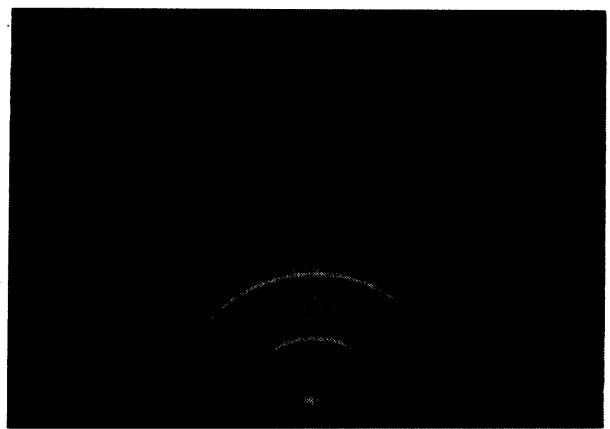

Photo.5 Electron diffractogram of rutiletype crystals formed on $\mathrm{Nb}$ in $0.1 \mathrm{~N} \mathrm{HNO}_{3}$ at $200^{\circ} \mathrm{C}$ for $1 \mathrm{hr}$

さてこれらの事実をもとに前述の新しい正方晶酸化物 ( $\mathrm{T}_{1}$ 相とする) について考察を進めるならば，つぎの事実 が明らかとなる.すなわち $\mathrm{HNO}_{3}$ 水溶液の濃度の上年とと もに $\mathrm{NbO}_{2}$ から $\mathrm{T}_{1}$ 相へと相転移の起こることが判明した。 またこの事実から，この正方晶 $\mathrm{T}_{1}$ 相の組成は颃そらく $\mathrm{NbO}_{2}$ よりも高次の $\mathrm{NbO}_{2}$ と $\mathrm{Nb}_{2} \mathrm{O}_{5}$ の中間相かあるいは $\mathrm{Nb}_{2} \mathrm{O}_{5}$ の多形の一種であろうと考えられる. な拉この相転 移は $0.5 \mathrm{~N} \mathrm{HNO}_{3}$ 中での酸化のさい $200^{\circ} \mathrm{C}$ から $250^{\circ} \mathrm{C}$ の 間で生じた。

(6) A.Magnéli, G.Andersson and G.Sundkvist : Acta Chem.Scand, 9 (1955), 1402.
以上の結果から明らかなように Ta の場合は $2 \mathrm{~N} \mathrm{HNO}_{3}$ 中でその表面に生成した準安定相 $\mathrm{TaO}_{2}$ が保護被膜となり 耐食性に寄与しているが，Nb の場合はそれより一層希薄 な $\mathrm{HNO}_{3}$ 中ではじめて $\mathrm{TaO}_{2}$ と同構造の $\mathrm{NbO}_{2}$ が腐食の barrier となっていることから判断して，Ta と比較すると かなり耐食性の点で劣ることがわかる. しかし $\mathrm{NbO}_{2}$ から 転移した $\mathrm{T}_{1}$ 相がかなり安定である事実から，より高濃度 の高温 $\mathrm{HNO}_{3}$ 水溶液中ではこの酸化物が保護被膜の役割を 果たしていると考えられる.

\section{2. $\mathrm{H}_{2} \mathrm{SO}_{4}$ 水溶液中における酸化被膜の構造}

$2 \mathrm{~N} \mathrm{H}_{2} \mathrm{SO}_{4}$ 水溶液中に $200^{\circ} \mathrm{C}$ および $300^{\circ} \mathrm{C} に 1 \mathrm{hr}$ 浸漬 した Ta の試料表面はそれぞれ淡黄色および黄褐色を示 し， $1 \mathrm{vol} \% \mathrm{HF}$ 中で剥離後電子回折の結果いずれも rutile 型結晶の存在を明示する回折像を得た. Photo. 6 は $300^{\circ} \mathrm{C}$, $1 \mathrm{hr}$ 酸化にさいし、て生成した被膜の直接観察像である.電 子回折像が $\mathrm{HNO}_{3}$ 中の場合と同じ rutile 型であり, 格子定 数も全く-致していることから，この $\mathrm{H}_{2} \mathrm{SO}_{4}$ 中で生成した 被膜はやはり $\mathrm{TaO}_{2}$ からなるあのと考えられるが，電顕に よる被膜の直接観察の結果は Photo. 1 と Photo. 6 にみられ るよ5に, 両酸水溶液の酸化性, 非酸化性などの性質の違 いが影響してか，かなり異なった被膜結晶の存在を示して いる.

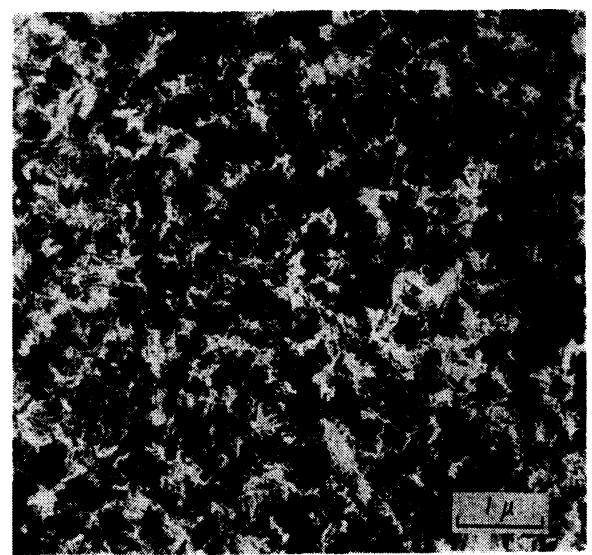

Photo.6 Transmission electron micrograph of oxide film formed on Ta in $2 \mathrm{~N}$ $\mathrm{H}_{2} \mathrm{SO}_{4}$ at $300^{\circ} \mathrm{C}$ for $1 \mathrm{hr}$

一方 $\mathrm{Nb}$ 試片を $2 \mathrm{NH}_{2} \mathrm{SO}_{4}$ 中に $200^{\circ} \mathrm{C}, 1 \mathrm{hr}$ 浸漬したと ころ，その表面には淡黄褐色の被膜が形成され，0.8 vol\% HF にて剝離後直接観察した結果, Photo.7 に示す微結晶 の存在が確認された.ところがこの被膜の電子回折の結果 またも未知物質を暗示する Photo.8 のよ5な回折像が得 られた，前と同様正方晶を基礎として成功裡になされた指 数付けの結果, $2 \mathrm{~N} \mathrm{HNO}_{3}$ 中で生成した $\mathrm{T}_{1}$ 相とは異なる $a_{0}=10.5 \check{\mathrm{A}}, c_{0}=5.85 \check{\mathrm{A}}, c_{0} / a_{0}=0.56$ の単位胞をむつ別の 正方晶物質 $\left(\mathrm{T}_{2}\right.$ 相とする)の存在が明らかとなった。 これ

(7) G.Brauer : Z.anorg.allg.Chem., 248 (1941), 1. 
らの指数ならびに計算された格子面間隔は Table 4 に与 兄られている。 この $2 \mathrm{~N} \mathrm{H}_{2} \mathrm{SO}_{4}$ 中で生成した被膜もかなり 安定であり， $300^{\circ} \mathrm{C}$ に扔いてもその構造を変えず，さらに $0.5 \mathrm{~N} \mathrm{H}_{2} \mathrm{SO}_{4}$ 中 $200^{\circ} \sim 300^{\circ} \mathrm{C}$, また $0.1 \mathrm{~N} \mathrm{H}_{2} \mathrm{SO}_{4}$ 中 $250^{\circ} \sim$ $300^{\circ} \mathrm{C}$ の条件下に扔いてもこの結晶の生成が認められた。 ところが $0.1 \mathrm{~N} \mathrm{H}_{2} \mathrm{SO}_{4} 200^{\circ} \mathrm{C}, 1 \mathrm{hr}$ 酸化の場合 $\mathrm{HNO}_{3}$ の とき同じ格子定数をるつ理想的な rutile 型結晶の生成を みたことから， $\mathrm{T}_{2}$ 相はやはり $\mathrm{NbO}_{2}$ より高次の酸化物であ ろらと考兄られるが，この組成についてはつぎの $\mathrm{HCl}$ 水 溶液中の実験に打いてさらに一層明らかにされる.

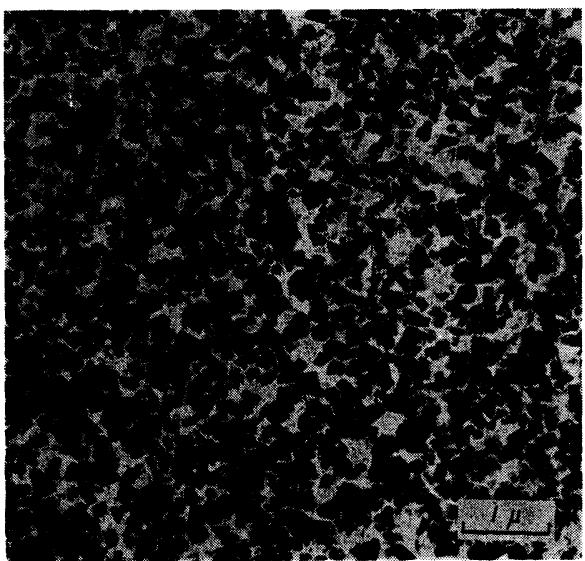

Photo.7 Transmission electron micrograph of oxide film formed on $\mathrm{Nb}$ in $2 N$ $\mathrm{H}_{2} \mathrm{SO}_{4}$ at $200^{\circ} \mathrm{C}$ for $1 \mathrm{hr}$



Photo.8 Electron diffractogram of $\mathrm{T}_{2}$-phase formed on $\mathrm{Nb}$ in $2 \mathrm{~N} \mathrm{H}_{2} \mathrm{SO}_{4}$ at $200^{\circ} \mathrm{C}$ for $1 \mathrm{hr}$

\section{3. $\mathrm{HCl}$ 水溶液中における生成被膜の構造}

今まで $\mathrm{HNO}_{3}$ ならびに $\mathrm{H}_{2} \mathrm{SO}_{4}$ 水溶液中に拈ける $\mathrm{Ta}$ 抽よ び $\mathrm{Nb}$ の耐食性に関する比較を構造的に観察してきたが, この完全な還元性酸である $\mathrm{HCl}$ 水溶液中に打いて両金属 の耐食性に歷然とした差のあることが明確になった.Ta の 高温高濃度の還元性酸中に和ける耐食性の優位は他金属の 追随を許さないきわだったものであることはすでによく知

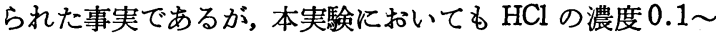
$2 N$, 温度 $200^{\circ} \sim 300^{\circ} \mathrm{C}$ の範囲内ではいかなる結晶性被膜 の生成もみられず，電子回折像の示した非晶質物質の存在 が強力な barrier となって耐食性に寄与しているものと考 えられる。

Table 4 Interplanar spacings $(d, \AA)$, intensities $(I)$ and indices $(h k l)$ of $\mathrm{T}_{2}$-phase formed on $\mathrm{Nb}$ in $2 \mathrm{~N} \mathrm{H}_{2} \mathrm{SO}_{4}$ at $200^{\circ} \mathrm{C}$ for $1 \mathrm{hr}$

\begin{tabular}{l|l|l|l}
\hline \hline$d_{\text {obs. }}$ & $d_{\text {calc. }}$ & $I_{\text {obs. }}$ & $h k l$ \\
\hline 5.24 & 5.25 & v.w. & 200 \\
3.93 & 3.91 & st. & 201 \\
3.74 & 3.72 & v. st. & 220 \\
3.49 & 3.50 & w. & 300 \\
3.32 & 3.32 & w. & 310 \\
3.12 & 3.13 & w. & 221 \\
2.81 & 2.81 & m.st. & 102 \\
2.72 & 2.72 & st. & 112 \\
2.60 & 2.60 & w. & 321 \\
2.29 & 2.29 & w. & 222 \\
1.96 & 1.95 & v.w. & 003,402 \\
1.92 & 1.92 & m.st. & 103,412 \\
1.88 & 1.89 & v.w. & 113,332 \\
1.83 & 1.83 & w. & 203,422 \\
1.75 & 1.75 & w. & 600 \\
1.72 & 1.72 & m.st. & 223,531 \\
1.60 & 1.60 & w. & 621 \\
1.55 & 1.55 & w. & 413 \\
\hline
\end{tabular}

ところが $2 \mathrm{~N} \mathrm{HCl}$ 水溶液中 $200^{\circ} \mathrm{C}, 1 \mathrm{hr}$ 加熱のさい $\mathrm{Nb}$ 表面に生成した黄色味を扣びた淡赤緑色の被膜は Photo.9 のような短冊状の組織からなり, 電子回折の 結果 Photo. 8 と同じ回折像を示した。この事実から生成被膜が $2 \mathrm{~N} \mathrm{H}_{2} \mathrm{SO}_{4}$ 中で生成した $\mathrm{T}_{2}$ 相と同構造の結晶からなることが判明し たが，同水溶液中での $250^{\circ} \mathrm{C}, 1 \mathrm{hr}$ の加熱では Photo.10 と Table 5 にみられるように主に $\delta$-形 $\mathrm{Nb}_{2} \mathrm{O}_{5}{ }^{\left({ }^{8}\right)}$ からなる 被膜の生成をみた。この事実と Photo.11 のこの被膜の直 接観察像が $\mathrm{Nb}$ のかなり激しい腐食の跡をとどめているこ ととから， $\mathrm{HCl}$ 水溶液中で生成した $\mathrm{T}_{2}$ 相はこの溶液中で は安定でなく最高次の酸化物へ移行していることがわか

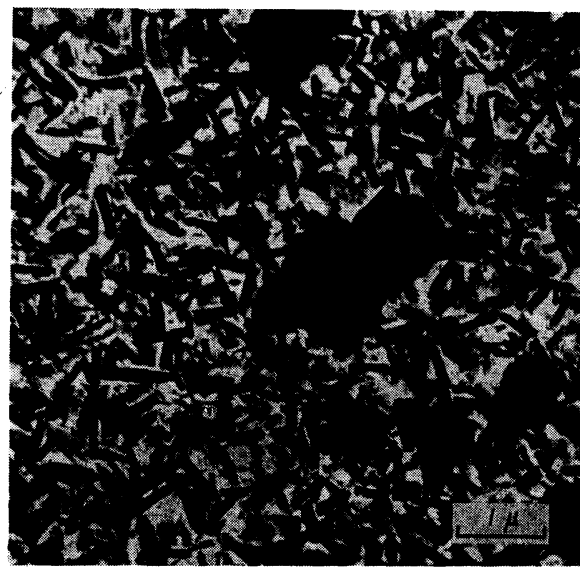

Photo.9 Transmission electron micrograph of oxide film formed on $\mathrm{Nb}$ in $2 N$ $\mathrm{HCl}$ at $200^{\circ} \mathrm{C}$ for $1 \mathrm{hr}$

(8) L. K. Frevel and H. N. Rinn : Analy. Chem., 27 (1955), 1329. 
る. な虾 Table 5 にみられる数本の未知な回折線化ついて は今のところ明らかではない。つぎに $0.5 \mathrm{~N} \mathrm{HCl}$ 中 $200^{\circ}$ $\sim 300^{\circ} \mathrm{C}$ で生成した被膜はいずれも前述の $\mathrm{HNO}_{3}$ 中で生成 した $\mathrm{T}_{1}$ 相と同しでありまた $0.1 \mathrm{~N} \mathrm{HCl}$ 中では結晶性の 被膜は形成されなかった。



Photo.10 Electron diffractogram composed mainly of $\delta$-phase $\left(\mathrm{Nb}_{2} \mathrm{O}_{5}\right)$ formed on $\mathrm{Nb}$ in $2 \mathrm{~N} \mathrm{HCl}$ at $250^{\circ} \mathrm{C}$ for $1 \mathrm{hr}$

Table 5 Interplanar, spacings obtained from the oxide film formed on $\mathrm{Nb}$ in $2 \mathrm{~N} \mathrm{HCl}$ at $250^{\circ} \mathrm{C}$ for $1 \mathrm{hr}$

\begin{tabular}{c|c|c|c|c}
\hline \multirow{2}{*}{$d_{\text {obs. }}$} & \multirow{2}{*}{$I_{\text {obs. }}$} & \multicolumn{3}{|c}{$\delta$-phase $\left\langle\mathrm{Nb}_{2} \mathrm{O}_{5}\right)^{(8)}$} \\
\cline { 3 - 5 } & & $d(\mathrm{~A})$ & \multicolumn{1}{c}{$I / I_{1}$} & $h k l$ \\
\hline 3.93 & st. & 3.925 & 90 & 001 \\
3.43 & m.st. & & & \\
3.13 & v.st. & 3.124 & 100 & 100 \\
2.56 & m.st. & & & \\
2.45 & st. & 2.446 & 40 & 101 \\
2.26 & w. & & & \\
1.97 & w. & 1.962 & 30 & 002 \\
1.81 & w. & 1.800 & 25 & 110 \\
1.76 & m.st. & & & \\
1.72 & w. & & \\
1.67 & m.st. & 1.663 & 30 & 102 \\
1.64 & w. & 1.637 & 14 & 111 \\
1.57 & w. & 1.565 & 12 & 200 \\
\hline
\end{tabular}

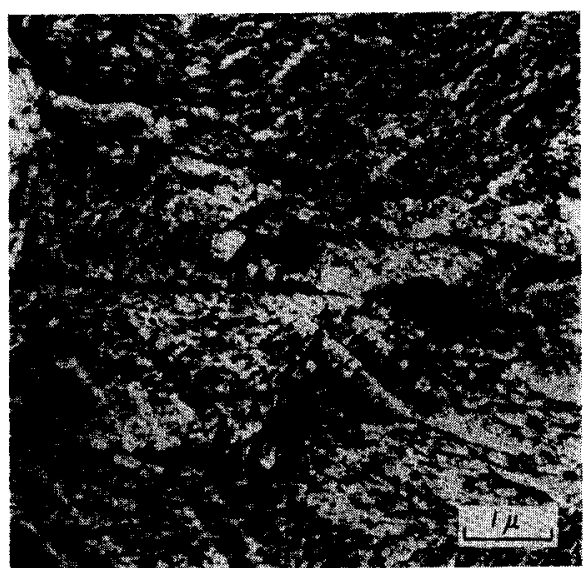

Photo.11 Transmission electron micrograph of oxide film formed on $\mathrm{Nb}$ in $2 \mathrm{~N}$ $\mathrm{HCl}$ at $250^{\circ} \mathrm{C}$ for $1 \mathrm{hr}$
以上の結果ををとめると， $\mathrm{HCl}$ 水溶液中で $\mathrm{Nb}$ 表面に生 成した酸化物の相転移の経過から， $T_{1}$ 相は $T_{2}$ 相よりも低 次の酸化物であると考えられ，酸化物の組成の上からでは $\mathrm{NbO}_{2} \rightarrow \mathrm{T}_{1}$ 相 $\rightarrow \mathrm{T}_{2}$ 相 $\rightarrow \mathrm{Nb}_{2} \mathrm{O}_{5}$ のような構造変化をたどるす の上推論される。林酸水溶液が酸化性から還元性一之 変化するにつ礼て Nb 表面により高次と思われる酸化物の 生成をみたことは興味深い。また $0.1 \mathrm{~N} \mathrm{HCl}$ 中における非 晶質被膜は $\mathrm{HCl}$ 中に捄ける Ta 表面のそれと役割を同じ くし，Nb の耐食性に寄与しているものと考兄られる。な 招 $\mathrm{HCl}$ 中では理想的な rutile 型構造をるつ $\mathrm{NbO}_{2}$ 被膜は 形成されなかった。

\section{IV. 粉 括}

高温 $\mathrm{HNO}_{3}, \mathrm{H}_{2} \mathrm{SO}_{4}$ あるいは $\mathrm{HCl}$ 水溶液中に括ける $\mathrm{Ta}$ 招よび $\mathrm{Nb}$ の耐食性被膜の組成括よび構造を電影ならびに 電子回折により観察した結果，つぎのような結果が得られ た.

(1) Ta 怯 $2 \mathrm{~N} \mathrm{HNO}_{3}$ 中 $200^{\circ} \sim 300^{\circ} \mathrm{C}$ 亿招いて表面に rutile 型 $\mathrm{TaO}_{2}$ 被膜の形成をみたが， $\mathrm{Nb}$ は $2 \mathrm{~N} \mathrm{HNO}_{3}$ 中 $200^{\circ} \sim 300^{\circ} \mathrm{C}$ で新しい正方晶酸化物 ( $\mathrm{T}_{1}$ 相: $a_{0}=8.94 \AA$, $\left.c_{0}=11.9 \AA ， c_{0} / a_{0}=1.33\right)$ がその表面に形成され, $\mathrm{HNO}_{3}$ の 濃度が低くなるにつれて重格子反射を含まない理想的な rutile 型結晶 $\left(a_{0}=4.75 \AA ， c_{0}=3.10 \AA, c_{0} / a_{0}=0.65\right) \mathrm{NbO}_{2}$ の観察が可能となった。このことから $\mathrm{T}_{1}$ 相は $\mathrm{NbO}_{2}$ より あ高次の酸化物であるうと考兄られる.

(2) $2 \mathrm{~N} \mathrm{H}_{2} \mathrm{SO}_{4}$ 中では Taは $\mathrm{HNO}_{3}$ 水溶液中上同し $\mathrm{TaO}_{2}$ 被膜によって被覆されたが， $\mathrm{Nb}$ は同水溶液中 $200^{\circ} \sim 300^{\circ} \mathrm{C}$ 飞招いて $\mathrm{T}_{1}$ 相とは異なる別の正方晶酸化物被膜 ( $\mathrm{T}_{2}$ 相： $\left.a_{0}=10.5 \dot{A}, c_{0}=5.85 \AA ， c_{0} / a_{0}=0.56\right)$ がその表面に形成さ れ，この被膜が $\mathrm{H}_{2} \mathrm{SO}_{4}$ 水溶液中での $\mathrm{Nb}$ の耐食性に寄与し ているすのと考穴られる。 なお $0.1 \mathrm{~N} \mathrm{H}_{2} \mathrm{SO}_{4} 200^{\circ} \mathrm{C}, 1 \mathrm{hr}$ 酸化沁小て $\mathrm{HNO}_{3}$ 水溶液中之同種の理想的な rutile 型 結晶の生成をみたことから， $\mathrm{T}_{2}$ 相もやはり $\mathrm{NbO}_{2}$ 上りも高 次の酸化物であるうと推論される。

(3) $\mathrm{Ta}$ は濃度 $2 N$ までの $\mathrm{HCl}$ 水溶液中では結晶性の被 膜が観察されず，この非晶質被膜が Ta の還元性酸に対す る強力な barrier となっているすのと考光られる。一力 $\mathrm{Nb}$ は $\mathrm{HCl}$ 中ではかなり耐食性が悪く, $2 \mathrm{~N} \mathrm{HCl} 200^{\circ} \mathrm{C}, 1 \mathrm{hr}$ 飞招いて $\mathrm{T}_{2}$ 相の生成が双られたが，同水溶液中 $250^{\circ} \mathrm{C}$, $1 \mathrm{hr}$ の加熱にさいして主に $\delta$-形 $\mathrm{Nb}_{2} \mathrm{O}_{5}$ へと相転移した. また $0.5 \mathrm{~N} \mathrm{HCl}$ 中 $200^{\circ} \sim 300^{\circ} \mathrm{C} て ゙ \mathrm{~T}_{1}$ 相の生成が 観察さ れたことから，酸水溶液中に淤りる構造变化は $\mathrm{NbO}_{2} \rightarrow \mathrm{T}_{1}$ 相 $\rightarrow \mathrm{T}_{2}$ 相 $\rightarrow \mathrm{Nb}_{2} \mathrm{O}_{5}$ の経過をたどるすのと考えられる。な拉 $0.1 \mathrm{~N} \mathrm{HCl}$ 中で法非晶質被膜しか観察されなかったので, これが $2 N \mathrm{NCl}$ 中で Ta 表面に形成された被膜と同じ役 割を果しているものと推論される。

最後に本研究を行なうにあたり，終始実験に協力された 北田韶彦，小川欽也，林 博行の各氏に深甚なる謝意を表 します。 